\title{
Appointment of new Editor for the Journal of Anglican Studies
}

The Trustees of the Journal of Anglican Studies are pleased to announce the appointment of The Rev'd Professor Brian Douglas in succession to Professor Peter Sherlock. We thank Professor Peter Sherlock for his contribution to the JAS and wish him well in his responsibilities as Vice Chancellor of the University of Divinity in Melbourne.

Brian Douglas is a distinguished liturgical scholar with an international reputation for high quality research and writing. He is an Adjunct Research Professor at the Australian Centre for Christianity and Culture within Charles Sturt University. He is a member of Societas Liturgica and other learned societies.

He has published numerous articles in academic journals and recent books include The Anglican Eucharist in Australia: The History, Theology and Liturgy of the Eucharist in the Anglican Church of Australia (Brill, 2021), The Eucharistic Theology of Edward Bouverie Pusey: Sources, Context and Doctrine within the Oxford Movement and Beyond (Brill, 2015) and the two volume work A Companion to Anglican Eucharistic Theology (Brill, 2012). His current project is Sacramental Poetics in Richard Hooker and George Herbert: Exploring the Abundance of God which explores the work of Richard Hooker and George Herbert as well as examining the wider issues of sacramental poetics.

Brian has served with great distinction as the Review Editor for the Journal of Anglican Studies, a role he will now relinquish as he takes up the responsibilities of Editor of this Journal. The Trustees are delighted to have the services of such scholar in the development of the Journal of Anglican Studies.

Dr Graeme L Blackman AO

Chairman

Journal of Anglican Studies Trust

Cite this article: Dr Blackman AO, G.L. (2021). Appointment of new Editor for the Journal of Anglican Studies. Journal of Anglican Studies 19, 1. https://doi.org/10.1017/S1740355321000115 